\title{
PERKEMBANGAN POLA PIKIR MASYARAKAT TERHADAP PENGELOLAAN SAMPAH DI DESA KARANGREJO KECAMATAN PURWOSARI, KABUPATEN PASURUAN
}

\author{
Muh. Aniar Hari Swasono ${ }^{1}$, Fatimatuz Zahroh ${ }^{2}$, Ria Mutiara ${ }^{3}$, Imroatun Nabila ${ }^{4}$, Tian Zahril \\ Mufidah $^{5}$ \\ ${ }^{1)}$ Dosen, Fakultas Pertanian, Universitas Yudharta Pasuruan, Jawa Timur, Indonesia \\ ${ }^{2,3)}$ Mahasiswa Psikologi, Fakultas Psikologi, Universitas Yudharta Pasuruan, Jawa Timur, Indonesia \\ ${ }^{4)}$ Mahasiswa Agribisnis, Fakultas Pertanian, Universitas Yudharta Pasuruan, Jawa Timur, Indonesia \\ ${ }^{5)}$ Mahasiswa Tekhnik Sipil, Fakultas Tekhnik, Universitas Yudharta Pasuruan, Jawa Timur, Indonesia \\ email : aniarhari@yudharta.ac.id
}

\begin{abstract}
Abstrak
Sampah adalah output dari masyarakat yang dianggap barang tidak berguna namun dengan semakin berkembangnya teknologi, maka nilai sampah kedepannya akan meningkat dan menjadi lahan usaha baru masyarakat. Desa Karangrejo Kecamatan Purwosari merupakan desa yang berkembang pesat dalam pertumbuhan ekonomi dan kesejahteraan masyarakat. Seiring dengan hal tersebut potensi sampah semakin besar sehingga perlu penanganan serius, salah satu upaya yang dilakukan adalah ingin merubah Mindset sebagian masyarakat itu dengan menanamkan pikiran bahwa "GARBAGE IS GOLD" atau sampah adalah emas. Mindset ini kita tanamkan agar masyarakat mampu mengelola sampah dan menjadikanya lapangan pekerjaan sehingga sampah yang keluar dari masyarakat dan diangkut oleh Dinas Lingkungan Hidup hanyalah sampah yang benar-benar tidak dapat dikelola (residu). Sehubungan dengan ini, Pemerintahan Desa Karangrejo bekerjasama dengan Universitas Yudharta Pasuruan, Dinas Lingkungan Hidup (DLH), dan Forum Kabupaten Pasuruan Sehat (FKPS) mengadakan MOU untuk pembangunan Taman Edukasi sampah di Desa Karangrejo yang nantinya akan berisi tentang edukasi pemisahan sampah Organik, Non organik, dan Residu dan pembuatan kompos dari Sampah Organik. Kompos yang telah dibuat sebagian akan menjadi oleh-oleh para pengunjung dan sisanya akan masuk ke dalam BUMDes (Badan Usaha Miliki Desa) serta dijual kembali ke masyarakat ataupun dinikmati oleh petani yang ada di Desa Karangrejo tersebut.
\end{abstract}

Kata Kunci: Lingkungan, Pengelolaan Sampah, Garbage Is Gold

\begin{abstract}
Garbage is the output of a society that is considered a useless commodity but as technology grows, the future value of garbage will grow and become a new venture for society. The karangrejo district purwosari growth is a thriving village in economic growth and public prosperity. As the potential of garbage grows, therefore it needs serious attention, one of the attempts to change the mindset of most of the society by instilling the idea that "garbage is gold" or trash is gold. These mindsets we plant so that the public can manage the trash and create jobs so that the trash that comes out of the community and is transported by the environment service is just trash that can't be managed (residue). In this regard, the village government of karangrejo works closely with yudakuuan university, environmental service (DLH), and the regional management forum (FKPS) mou for the construction of garbage education parks in karangrejo village that will later contain the education of organic, non-organic garbage, and the residue and compost of organic litter. Partially manufactured compost would be souvenirs, and the rest would go into the BUMDes and be resold into the community or enjoyed by the farmers in the karangrejo village
\end{abstract}

Key Words: Environment, Waste Management, Garbage is Gold 


\section{PENDAHULUAN}

Permasalahan lingkungan saat ini tidak hanya terdapat dari satu wilayah saja, akan tetapi terdapat dari berbagai wilayah. Permasalahan ini menyangkut pencemaran yang diakibatkan oleh aktivitas manusia. Salah satunya adalah sampah. Sampah yang saat ini menjadi PR besar bukan hanya bagi pemerintah pusat. Akan tetapi pemerintah daerah maupun desa. Apabila sampah dari wilayah desa tidak mendapat perhatian bagi pemerintah, bukan tidak mungkin akan mengakibatkan pencemaran di udara, air, maupun tanah sekitar tempat penumpukan sampah tersebut.

Berdasarkan SK SNI Tahun 1990, sampah adalah limbah bersifat padat dan juga setengah padat, dari bahan organik atau anorganik, baik benda logam maupun benda bukan logam, yang dapat terbakar dan yang tidak dapat terbakar.terdiri dari zat organik dan zat anorganik yang dianggap tidak berguna lagi dan harus dikelola agar tidak membahayakan lingkungan dan melindungi investasi pembangunan berupa sisa-sisa bahan yang mengalami perlakuan-perlakuan, baik karena telah sudah diambil bagian utamanya, atau karena pengolahan, atau karena sudah tidak ada manfaatnya yang ditinjau dari segi sosial ekonomis tidak ada harganya dan dari segi lingkungan dapat menyebabkan pencemaran atau gangguan terhadap lingkungan hidup yang belum memiliki nilai ekonomi dapat menyebabkan pencemaran atau gangguan terhadap lingkungan hidup.

Bentuk fisik benda-benda tersebut dapat berubah menurut cara pengangkutannya atau cara pengolahannya. Sampah padat adalah semua barang sisa yang ditimbulkan dari aktivitas manusia dan binatang yang secara normal padat dan dibuang ketika tidak dikehendaki atau sia-sia.

Pengelompokan sampah dibagi menjadi 2 macam: berdasarkan bentuk dan asalnya.

1. Berdasarkan bentuk yaitu sampah padat, sampah cair, sampah gas.

- Sampah padat adalah semua jenis sampah dengan bentuk padat. Seperti :kotoran manusia, urin dan benda cair lainnya tidak termasuk jenis ini. Adapun jenis-jenisnya yaitu

- Sampah cair adalah jenis bahan yang berbentuk cairan, telah digunakan untuk kepentingan hidup manusia dan tidak lagi dibutuhkan. Pada akhirnya, sampah jenis ini akan dibuang. Misalnya berbagai sisa produksi pabrik yang berbentuk cair.

- Sampah gas adalah proses pembakaran atau pembusukan suatu bahan. Limba gas dapat diidentifikasi dari adanya warna, udara, bau, dan rasa. Seperti: Karbon Monoksida (CO), Karbon Dioksida $\left(\mathrm{CO}_{2}\right.$ ), Sulfur Dioksida (SO2), Gas Amonia (NH3), Gas metan (CH4), (https://republikseo.net/sampah/)

2. Berdasarkan asalnya : sampah rumahtangga, sampah perkotaan, sampah industri

- Sampah rumahtangga merupakan bahan sisa yang dihasilkan dari kegiatan rumah tangga. Contoh sampah organik maupun anorganik, detergen, kotoran, dan asap hasil pembakaran. pembuangan sampah yang tidak teratur dan menyebabkan pencemaraan air, udara, dan tanah. Selain itu contoh pembuangan sampah, pembuangan limbah mandi, cuci, dan kakus masih banyak yang dibuang ke sungai.

- Sampah perkotaan, adalah limbah yang bersifat padat dan terdiri dari bahan organik dan anorganik yang dianggap tidak berguna lagi dan harus dikelola agar tidak membahayakan lingkungan dan melindungi investasinpembangunan yang timbul di kota.

- Sampah industri adalah. Sampah yang dihasilkan dari kegiatan industri kebanyakan tergolong ke dalam jenis limbah B3. Sehingga sebelum dilakukan pembuangan harus melalui pengolahan khusus dan penetralan agar pada saat dibuang, aman bagi lingkungan. Banyak pabrik yang tidak memerhatikan faktor lingkungan ketika membuang limbah. Misalnya saja, limbah tidak diolah terlebih dahulu sebelum dibuang ke perairan. Hal ini sangat berbahaya bagi organisme yang hidup di perairan. Ikan-ikan akan mati karena terdapat bahan beracun dari limbah yang dibuang ke perairan. Berikut adalah gambar pembuangan limbah yang dilakukan oleh industri.

- (http://www.biomagz.com/2016/03/pengertian-dan-contoh-limbah-limbah.html)

Pada tahun 2019 terdapat data yang menyatakan bahwa Produksi sampah di Indonesia hingga 67,1 juta ton. Berdasarkan Sistem Informasi Pengelolaan Sampah Nasional (SIPSN) tahun 20172018 diketahui bahwa di Kabupaten Pasuruan menghasikan 1.130 ton sampah berasal dari timbunan sampah rumahtangga setiap harinya. Menurut wawancara dari kepala desa Karangrejo, menyebutkan bahwa sampah di Desa Karangrejo tiap harinya berkisar 1-2 Ton. Hal ini perlu diperhatikan agar tidak semakin bertambah banyak timbunan sampah yang berada di wilayah ini. Sehingga kami, mengajak untuk melakukan kegiatan GEMAS (Gerakan Masyarakat Memilah 
Sampah) dengan tujuan agar masyarakat Desa Karangrejo mampu mengelola sampah dengan baik. Karena beberapa sampah pada nyatanya bisa dikelola lagi dan menghasilkan uang. Serta harapan penulis dan tim adalah sampah yang keluar dari rumahtangga warga dan produksi rumahan hanya sampah yang bersifat Residu atau sampah yang tidak bisa dijadikan kompos maupun sampah yang tidak memiliki daya jual.

\section{METODE}

Kegiatan ini dilakukan pada bulan Juli-Agustus 2020 dan berlokasi di Desa Karangrejo Kecamatan Purwosari Kabupaten Pasuruan Jawa Timur. Penulis dan tim memilih menggunakan metode analisis kualitatif. Teknik penelitian ini dilakukan dengan cara survei lapangan yaitu Focus Group Discussion (FGD) yang melibatkan partisipan,wawancara terbuka, dan studi literatur.

Data Kualitatif penulis dan tim gunakan untuk mengetahui informasi terkait penanganan sampah yang ada pada lingkungan Desa Karangrejo secara observasional/survei lapangan dilakukan untuk melihat kondisi nyata yang ada dilapangan sehingga diketahui secara benar apa yang sedang terjadi. Focus Group Discussion (FGD) dilaksanakan dengan menyertakan beberapa perangkat desa, organisasi yang ada di desa, karang taruna,dan penulis dan tim Universitas Yudharta Pasuruan. Focus Group Discussion yang dilakukan memiliki topik tentang pengelolaan sampah yang ada di Desa Karangrejo. Hasil dari Wawancara terbuka yang dilakukan dengan kepala desa Karangrejo akan dilanjutkan pembahasanya dengan staff Dinas Lingkungan Hidup (DLH) Kabupaten Pasuruan, dan ketua Forum Kabupaten Pasuruan Sehat (FKPS). Populasi dari penelitian ini mengambil dari organisasi (karang taruna, pemuda yang ada di desa, ibu-ibu PKK, dan perangkat desa yang diwakili oleh Badan Perwakilan Desa (BPD).

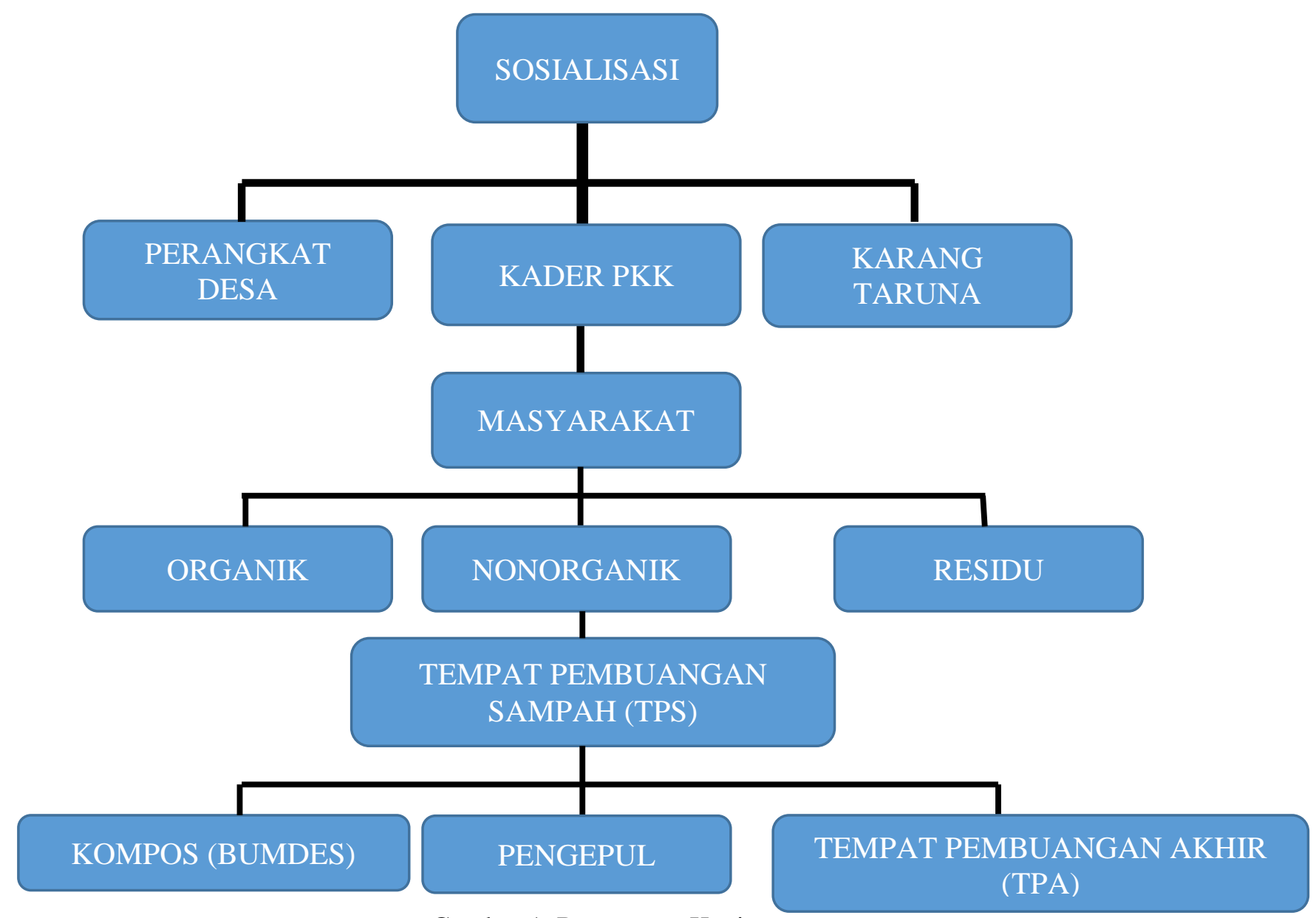

Gambar 1. Rancangan Kegiatan 


\section{HASIL DAN PEMBAHASAN}

Wilayah Desa Karangrejo terletak pada wilayah dataran Tinggi Dengan kordinat antara 650m, dengan luas $5,05 \mathrm{~km}^{2}$ atau $505 \mathrm{ha}$, dengan batas-batas wilayah, sebagai berikut:

- Sebelah Utara : Desa Sukorejo Kecamatan Sukorejo

- Sebelah Timur : Desa Sumbersuko Kec. Purwosari

- Sebelah Selatan: Desa Cendono Kecamatan Purwosari

- Sebelah Barat : Desa Watuagung Kecamatan Prigen

Pusat pemerintahan desa Karangrejo terletak di dusun Damarjati /RT 002/RW 005 dengan menempati areal lahan seluas $3.000 \mathrm{M}^{2}$.

Dengan Jumlah penduduk desa Karangrejo sebanyak 6428 jiwa yang tersebar di 3 (tiga) Dusun, 7 RW dan 33 RT. Dari jumlah tersebut, terdiri dari laki-laki 3400 jiwa dan perempuan 3024 jiwa dengan tingkat pertumbuhan rata-rata selama 6 (enam) tahun terakhir 1,8\%, dengan tingkat kepadatan sebesar $18 \mathrm{jiwa} / \mathrm{km}^{2}$. (Data buku kependudukan desa Karangrejo)

Desa Karangrejo Kecamatan Purwosari, Kabupaten Pasuruan-Jawa Timur mengalami kendala dalam mengelola sampah Rumah Tangga serta Home Industri karena pada kenyataanya 60\% masyarakat yang bekerja sebagai wirausaha belum memiliki solusi tentang Tempat Pembuangan Sampah Sementara (TPS) atau Tempat Pembuangan Akhir (TPA) sehingga masyarakat lebih memilih membakar sampah pada malam hari, ada pula yang membuang ke sungai atau lapangan di Desa Karangrejo daripada mengelolanya.

Menurut Ikhsandri (2014), mengatakan bahwa tindakan membakar sampah merupakan salah satu teknik pengolahan sampah, akan tetapi pembakaran sampah dilakukan di lapangan yang jauh dari pemukiman. Namun, pembakaran seperti ini susah dikendalikan karena terdapat asap, angin kencang, debu, dan arang sampah yang mana akan terbawa ke tempat sekitar sehingga menimbulkan polusi. Pembakaran yang paling baik yaitu dilakukan dengan insinerator agar tidak menimbulkan gangguan akan tetapi memerlukan biaya yang mahal.

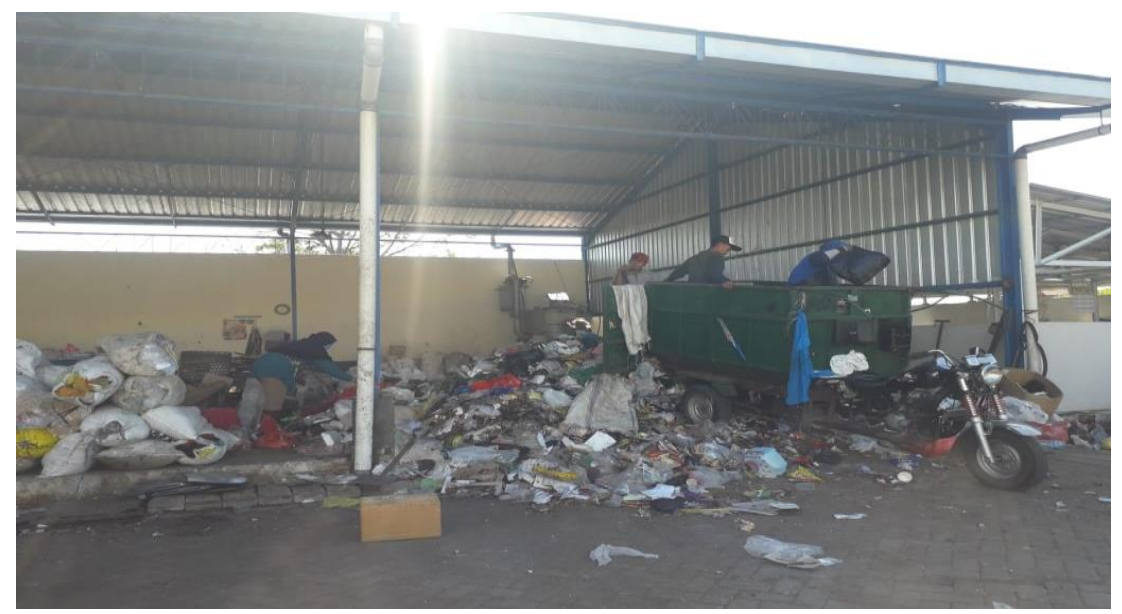

Gambar 1: TPS Desa Glagahsari Kecamatan Sukorejo

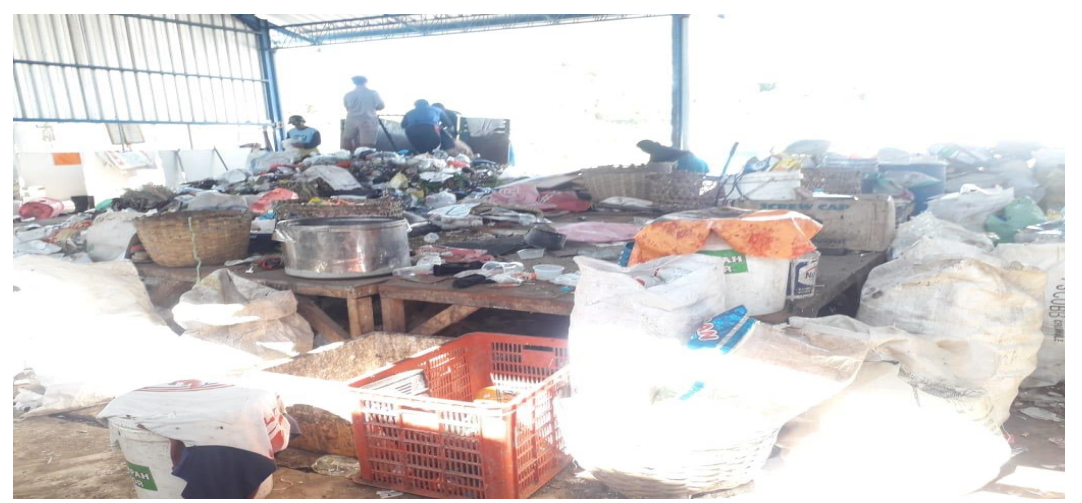

Gambar2: Proses Pemilahan sampah di Desa Glagahsari Kecamatan Sukorejo 
Tempat Pembuangan Sampah Desa Glagahsari Kecamatan Sukorejo yang lokasinya berdekatan dengan Desa Karangrejo sebagai pecontohan oleh pihak Desa Karangrejo dan Tim dari Universitas Yudharta Pasuruan sebagai Tempat Pembuangan Sampah (TPS). Gambar diatas adalah foto sampah yang baru diangkut dari masyarakat menggunakan Tossa dan baru dilakukan pemilahan di Tempat tersebut. Sehingga akan menambah pengeluaran desa untuk memberikan gaji kepada pekerja yang melakukan pemilahan sampah menjadi 3 bagian. Hal tersebut menjadikan evaluasi bagi penulis dan tim untuk melakukan pencapaian dengan menggerakkan warga untuk memilah sampah di masingmasing rumah agar meminimalisir dana yang akan dikeluarkan warga dan pemerintah desa.

Memacu pada negara maju seperti Korea Selatan yang sudah melakukan pemilahan sampah di rumah masing-masing dengan tujuan untuk mendisiplinkan warga dan mempermudah pekerja yang bekerja di Tempat Pembuangan Sampah (TPS) untuk melakukan kegiatan atau proses setelahnya.

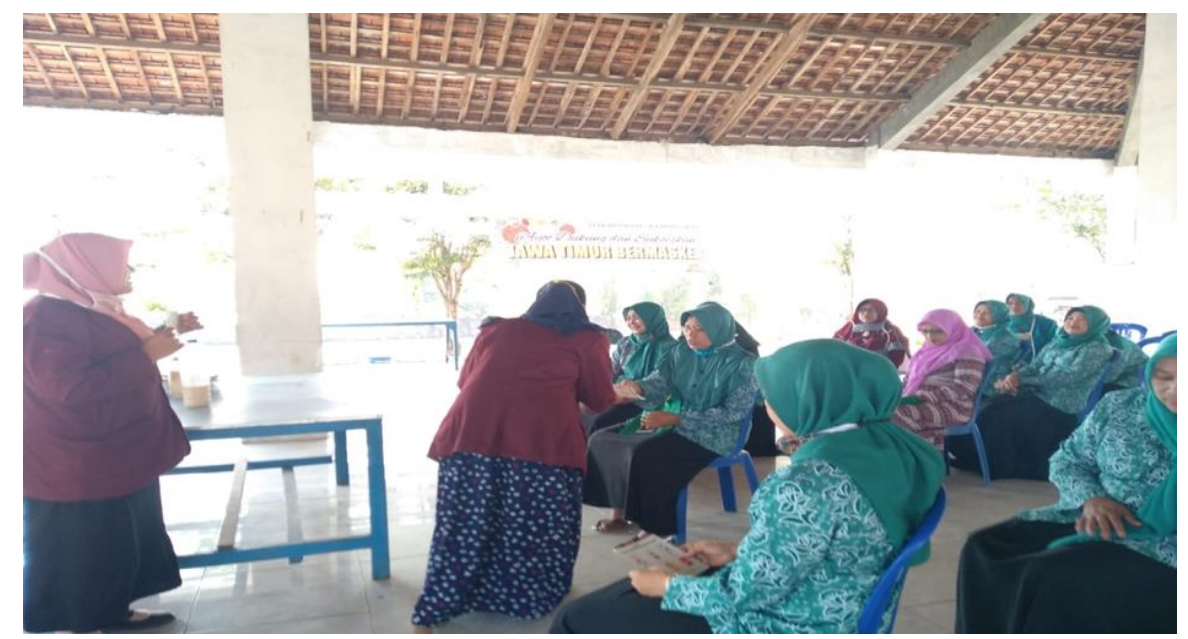

Gambar 3. Sosialisasi dan Pembagian Stiker GEMAS

Penulis dan Tim yang sedang menjalani Program pengabdian masyarakat di Desa Karangrejo ingin merubah serta menumbuhkan Mindset para warga yang menganggap sampah adalah hal yang menjijikan menjadi sesuatu yang berharga melalui program GEMAS (GErakan Masyarakat memilAh Sampah), edukasi ini diberikan agar masyarakat tidak semua sampah dijadikan satu lalu dibuang dengan satu plastik besar. Program ini juga bertujuan untuk menambah wawasan warga mengenai pengelompokkan sampah, serta pengelolaan masing-masing dari pengelompokkan sampah seperti sampah organik, sampah organik adalah sampah yang berasal dari sisa makanan, buah, serta ranting dan daun. Sampah anorganik yaitu sampah yang dihasilkan dari bahan-bahan nonhayati yang tidak dapat diuraikan oleh alam tetapi dapat di daur ulang. Seperti botol plastik, koran, kardus, majalah. Dan yang terakhir adalah sampah Residu. Sampah Residu merupakan sampah yaang tidak termasuk sampah Organik maupun nonorganik sehingga tidak dapat di daur ulang serta dijual kembali. Contoh sampah Residu seperti Pampers, pembalut,dll.

Sebelum melakukan program GEMAS, hanya sekitar $15 \%$ kader PKK yang mampu menjawab golongan-golongan sampah yang akan kita laksanakan. Sedangkan paska sosialisasi GEMAS terdapat 60\% kader PKK yang memahami pengelompokkan sampah di masyarakat. Dan hal ini menjadi acuan penulis dan tim untuk melakukan gerakan ini menjadi kelompok yang lebih besar.

Berikut ini adalah penjelasan mengenai pengelompokkan sampah kepada masyarakat:

Yang pertama adalah sampah Organik yaitu sampah yang berasal dari sisa bahan makanan seperti buah, sayur, daun kering, dan ranting serta dapat didaur ulang menjadi kompos atau pupuk dan mol dengan beberapa cara seperti komposter, Takakura, dan Biopori yang nantinya bisa dimanfaatkan oleh masyarakat maupun petani untuk tanaman atau lahan pertanian. Penulis daan tim berharap masyarakat dan para petani dapat meminimalisir biaya pemeliharaan tanaman yang berada di desa Karangrejo ini dengan pupuk buatan yang dibuat oleh masyarakat dari sisa makanan di Rumah Tangga yang berupa kompos atau MOL (Mikro Organisme Lokal) yang bisa dijadikan pupuk organik yang bisa dijual dengan harga Rp.20.000/liter. Kegiatan ini diharapkan mampu menjadi pemasukan bagi warga sekitar dan tentunya BUMDes (Badan Usaha Milik Desa) Karangrejo apabila diproduksi secara masal. 


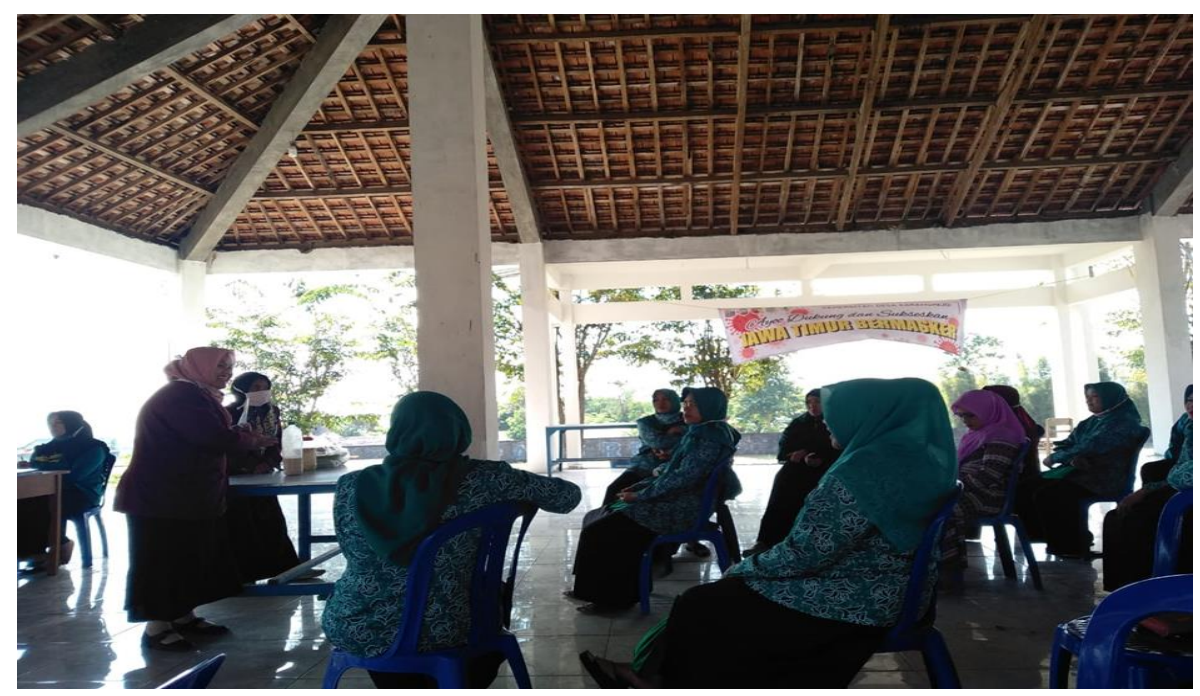

Gambar 4. Sosialisasi pembuatan MOL (Mikro Organisme Lokal) dari nasi dan gula

Untuk pembuatan pupuk dari tiap rumah, kita bisa menggunakan cara kompos atau takakura ataupun mol. Jika ibu rumah tangga melakukan pembuatan pupuk berkelompok yang terdiri dari 3-5 rumah bisa menggunkan Komposter ataupun Biopori. Sedangkan jika membuat pupuk dengan kapasitas yang lebih besar seperti satu desa, bisa kita gunakan Juglangan atau lubang untuk pembuatan biopori.

Sampah anorganik yaitu sampah yang dihasilkan dari bahan-bahan nonhayati yang tidak dapat diuraikan oleh alam tetapi dapat di daur ulang. Seperti botol plastik, koran, kardus, majalah yang nantinya bisa dijual kembali dengan harga yang disesuaikan oleh pengepul sehingga dapat meminimalisir output sampah rumah tangga dan mengubahnya menjadi barang-barang rumah tangga seperti piring, gelas, dan mangkok.

Sampah Residu merupakan sampah yang tidak termasuk sampah Organik maupun nonorganik sehingga tidak dapat di daur ulang serta dijual seperti Pampers, pembalut, kaset $C D$, dll. Hal ini merupakan masalah bagi warga sekitar apabila ditumpuk terus menerus akan mengurangi estetika dari wilayah tersebut. Sampah yang termasuk golongan residu ini yang nantinya akan berada di Tempat Pembuangan Akhir di Desa Karangrejo, Kabupaten Pauruan Jawa Timur.

Setelah melakukan Sosialisas GEMAS, penulis dan tim pun melaksanakan Sosialisasi pembuatan MOL. Sosialisasi pembuatan MOL ini diikuti oleh kader Ibu PKK sebanyak 20 orang. Dari 20 kader PKK pada awal sosialisasi, terdapat $\mathbf{1 0 \%}$ yang mengetahui tentang MOL sedangkan yang lainya tidak mengetahui. Oleh sebab itu penulis melakukan Sosialisasi pembuatan MOL kepada ibu PKK agar dapat mempraktekanya dan memanfaatkan sisa nasi yang biasanya dibuat untuk pakan ternak bisa dimanfaatkan untuk nutrisi pada tanaman. Paska Sosialisasi pembuatan MOL (Mikro Organisasi Lokal) terdapat $\mathbf{7 5 \%}$ yang mengetahui tentang pembuatan MOL. 25\% Kader ibu PKK yang mengikuti Sosialisasi GEMAS dan MOL mulai menyisihkan sampah organik dari rumah tangga mereka untuk pembuatan MOL di rumah masing-masing dan memisahkan sampah nonorganik untuk dijual kepada pengepul dengan melakukan barter seperti gelas, mangkok, dan lain-lain. Hal ini akan terus berlanjut dan menjadi pantauan bagi Penulis dan tim untuk memperluas pengetahuan masyarakat hingga terbentuknya Tempat Pembuangan Sampah beserta Taman Edukasi Sampah pada Desa Karangrejo sendiri.

Tabel 1. Perencanaan Pengelolaan sampah

\begin{tabular}{|l|l|l|l|}
\hline KEGIATAN & \multicolumn{2}{|l|}{ TAHUN } \\
\cline { 2 - 4 } & 1 & 2 & 3 \\
\hline Sosialisasi Sampah & $\mathrm{X}$ & & \\
\hline Kegiatan Pemilahan Sampah & $\mathrm{X}$ & $\mathrm{X}$ & $\mathrm{X}$ \\
\hline Sosialisasi Bahan Organik menjadi kompos & $\mathrm{X}$ & $\mathrm{X}$ & $\mathrm{X}$ \\
\hline Kegiatan Bersih Desa & $\mathrm{X}$ & $\mathrm{X}$ & $\mathrm{X}$ \\
\hline Mengalokasikan Anggaran dana desa untuk pembangunan TPS & - & $\mathrm{X}$ & - \\
\hline Pembangunan Tempat penampungan Sampah Sementara & - & $\mathrm{X}$ & - \\
\hline Pengadaan alat Kebersihan dan tong sampah & $\mathrm{X}$ & $\mathrm{X}$ & $\mathrm{X}$ \\
\hline
\end{tabular}




\begin{tabular}{|l|l|l|l|}
\hline Pembangunan Tempat Penampungan Sampah Terpadu & - & $\mathrm{X}$ & $\mathrm{X}$ \\
\hline Pembangunan Taman Edukasi Sampah & - & $\mathrm{X}$ & $\mathrm{X}$ \\
\hline $\begin{array}{l}\text { Pengelolaan sampah organik menjadi pupuk secara masal sebagai oleh-oleh } \\
\text { pengunjung }\end{array}$ & - & - & $\mathrm{X}$ \\
\hline
\end{tabular}

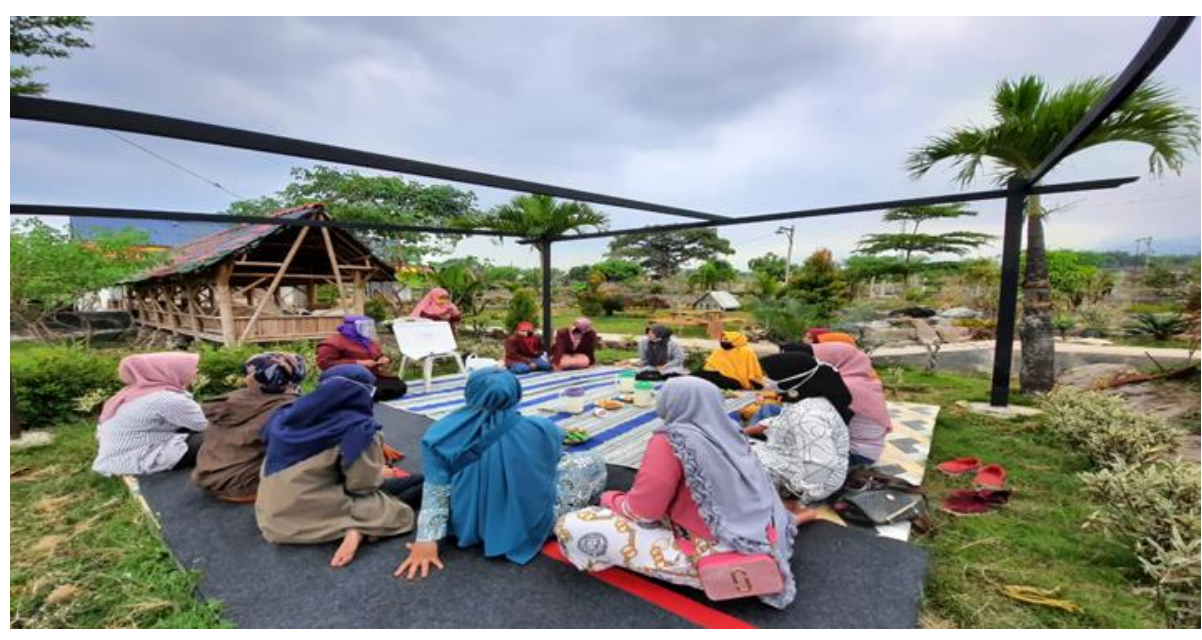

Gambar 5. Sosialisasi GEMAS I (GErakan MASyarakat memilah sampah)

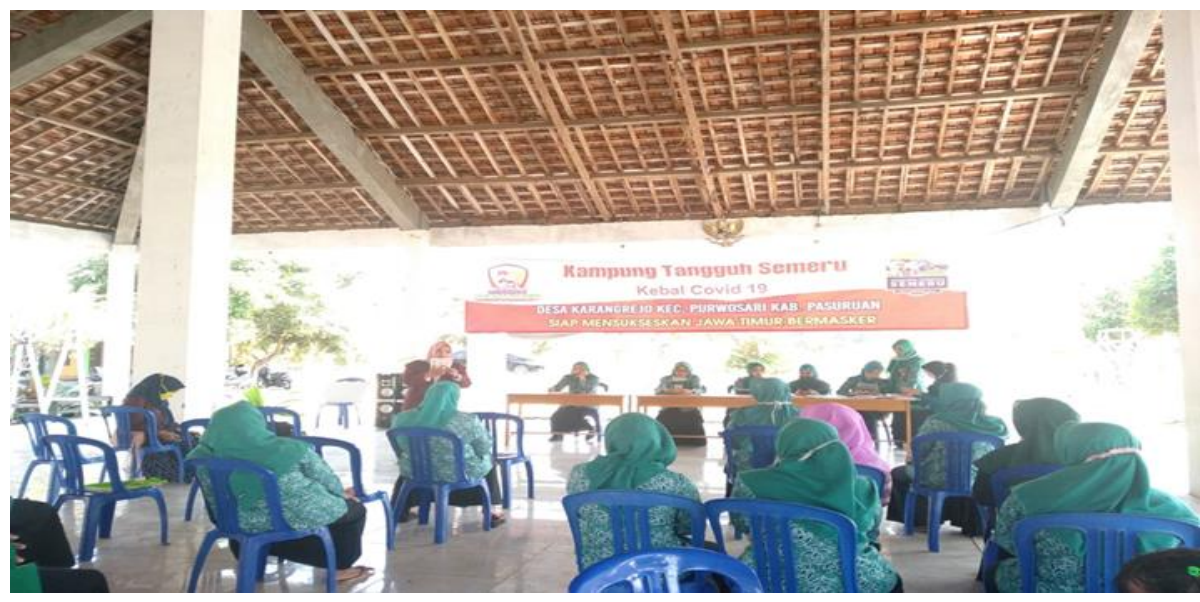

Gambar 6. Sosialisasi GEMAS II (GErakan MASyarakat memilah sampah)

Pemerintahan Desa, Karang taruna, dan Kader PKK masih memiliki semangat yang tinggi untuk memperbaiki desa. Diskusi ini menghasilkan beberapa solusi yakni mengajukan pembangunan TPS dan penyediaan tempat sampah kepada Dinas Lingkungan Hidup (DLH) Kabupaten Pasuruan karena faktor utama dari permasalahan sampah di Desa Karangrejo adalah fasilitas TPS dan transportasi untuk mengangkut sampah ke TPA. Solusi lainnya adalah mengalokasikan ADD (Alokasi Dana Desa) untuk membuat TPS dan tempat sampah untuk tiap rumah. Penulis juga memberikan solusi untuk gotong royong membersihkan lingkungan Desa Karangrejo sebagai langkah awal untuk meningkatkan kesadaran warga terhadap kebersihan lingkungan. Kegiatan gotong royong ini dapat dilaksanakan satu bulan satu kali dan dikoordinasikan oleh karang taruna dan organisasi remaja Karangrejo serta perangkat desa agar menjadi kegiatan rutin yang dilakukan di Desa Karangrejo. 


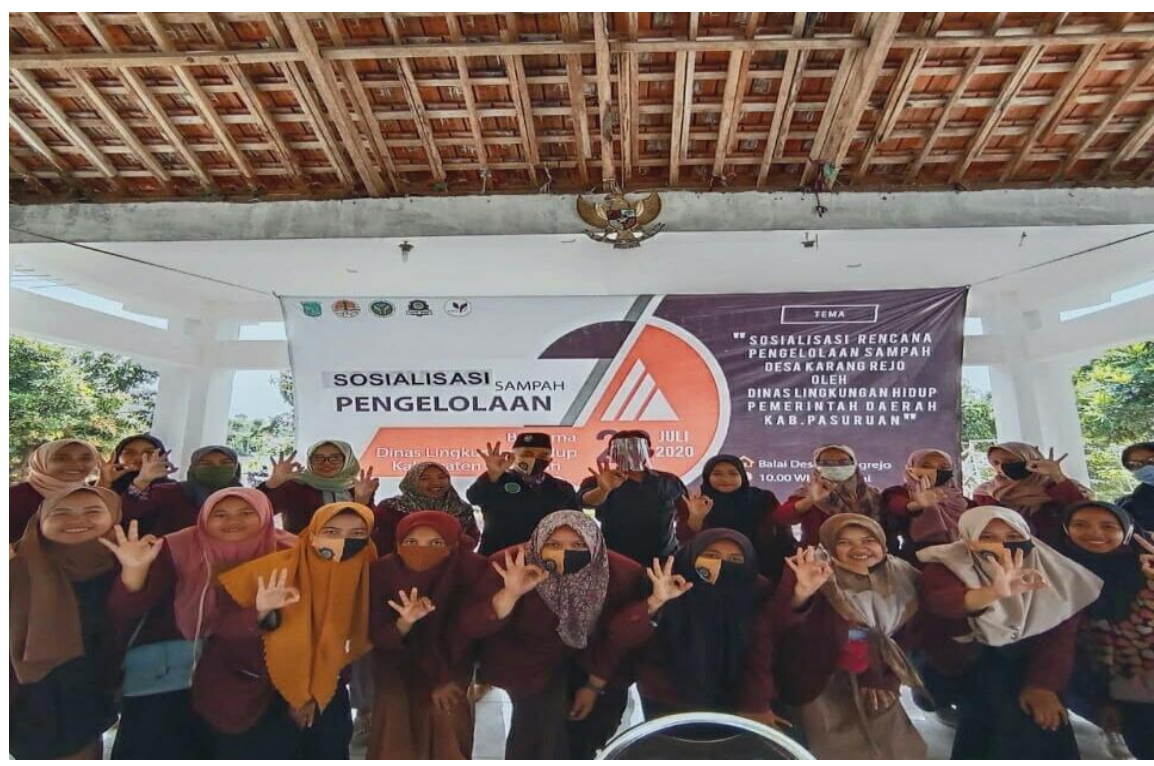

\section{Gambar 7. Sosialisasi Pengelolaan Sampah bersama Dinas Lingkungan Hidup(DLH) dan Forum Kabupaten Pasuruan Sehat (FKPS)}

Wawancara terbuka dilakukan dengan pihak pemerintah Kabupaten Pasuruan yang diwakili oleh staff Dinas Lingkungan Hidup (DLH). Topik pembicaraannya adalah tentang penanganan masalah sampah di Desa Karangrejo Kecamatan Purwosari Kabupaten Pasuruan. Pertama adalah terkait lahan yang akan digunakan untuk tempat penampungan sementara (TPS) dari sampah yang dihasilkan oleh masyarakat Desa Karangrejo. Hal ini menjadi bahan diskusi awal dikarenakan memang tidak adanya lahan yang kosong untuk tempat tersebut. Menurut kepala desa Karangrejo mengatakan bahwa perlunya penanganan sampah yang paling utama adalah pengadaan lahan untuk tempat penampungan sementara (TPS) di desa. Pemerintahan Desa beranggapan bahwa lahan tersebut nantinya akan dijadikan bangunan permanen ketika sudah berdiri tempat penampungan sementaranya.

Menurut Nurlela, 2017 mengatakan bahwa tempat pengolahan sampah sangat perlu diadakan karena memiliki dampak positif yang lebih besar dari pada dampak negatifnya adanya lahan Desa yang mampu dijadikan Tempat Pembuangan Sampah, maka Desa Karangrejo hanya menunggu alokasi dana untuk terealisasikanya tempat tersebut dan bekerjasama dengan instansi terkait.

Kedua adalah terkait pengelolaan dari sampah tersebut ketika sudah berdirinya Tempat Penampungan Sementara (TPS) di Desa Karangrejo. Hal ini sesuai dengan penelitian dari Triastantra, 2016 mengatakan bahwa fasilitas yang tidak memadai menjadikan sampah tersebut tidak bisa dikelola dengan baik. Pihak Dinas Lingkungan Hidup (DLH) memberikan masukan berupa penarikan iuran yang nantinya akan meminta tolong orang untuk mengantarkan sampah yang sudah terkumpul ke tempat pembuangan sementara yang sudah disediakan oleh pihak Dinas Lingkungan Hidup (DLH) dan bisa dibawa oleh truk pengambil sampah. Masukan kedua adalah dikarenakan memang akses yang tidak mudah untuk dijangkau, pemusnahan sampah dilakukan dengan cara pembuangan ke lahan kosong yang sudah dapat izin dari pemilik lahan yang nantinya bisa digunakan sebagai pondasi berdirinya suatu bangunan. Sampah tersebut bisa menjadi tambahan urug untuk suatu bangunan. Masukan ketiga adalah pemusnahan sampah dengan cara dibakar. Hal ini dilakukan sebagai opsi terakhir karena memang tidak bisa dipungkiri bahwa akses jalan ke desa sedang dalam pembangunan. Akan tetapi, pembakaran tidak boleh dilakukan disembarang tempat dan diusahakan yang jauh dari pemukiman sehingga tidak mengakibatkan timbulnya masalah kesehatan baru yang diakibatkan oleh pembakaran sampah tersebut.

Ketiga adalah terkait penyadaran masyarakat yang nantinya akan mengelola dan membuang sampah pada tempatnya/Tempat Penampungan Sementara (TPS) yang disediakan. Meningkatkan pola pikir (mindset) dari masyarakat tidaklah mudah dikarenakan ada hal-hal yang dianggap mistis, sudah membudaya, dan lain-lain sehingga perlunya pengaruh yang kuat dari pihak luar. Ketika terjadi pengaruh dari dalam sendiri (internal desa) maka bisa jadi perubahan pola pikir (stigma) tersebut berjalan tidak lebih dari satu minggu. Masyarakat beranggapan bahwa itu sudah menjadi kebiasaan 
dan orang tersebut pun tidak melakukan hal yang sama dengan apa yang dikatakan sehingga kebiasaan tersebut kembali seperti semula.

Masukan yang diberikan dari pihak Dinas Lingkungan Hidup (DLH) nantinya akan diadakan sosialisai tentang pengolahan sampah yang baik dan benar dikarenakan tingkat penyadaran yang utama adalah pengetahuan seseorang akan hal tersebut. Sosialisasi sudah dilakukan pada awal kegiatan, akan tetapi perlunya sosialisasi secara berkelanjutan dari pihak pemerintah/Dinas Lingkungan Hidup (DLH) dikarenakan tingkat kepercayaan masyarakat akan hal itu masih dirasa bisa memberikan dampak positif. Sosialisasi dilakukan oleh masyarakat sendiri, maka tingkat kepercayaan masyarakat masih dibawah 50\% dikarenakan pemateri tersebut bukan dari orang Dinas Lingkungan Hidup (DLH). Hal ini sesuai dengan penelitian dari Fajar, 2014 mengatakan bahwa memang tidak mudah merubah suatu perilaku atau kebiasaan dari masyarakat sehingga usaha yang dilakukan harus secara terus menerus (continue) dan dalam waktu yang lama.

Keempat adalah terkait pengolahan sampah yang bisa dimanfaatkan. Melakukan upaya pemanfaatan sampah yang bisa digunakan sebagai bahan daur ulang adalah salah satu upaya untuk mengurangi sampah. Pada tahun ini sudah tidak lagi malu untuk membuat bahan produk jadi yang berasal dari daur ulang sampah yang masih bisa digunakan dan layak. Dari pihak Dinas lingkungan Hidup (DLH) memberikan masukan berupa adanya pelatihan keterampilan untuk warga dalam melakukan pengolahan sampah. Akan tetapi hal tersebut tidak mudah dilakukan karena tidak semua orang mau berkecimpung dalam dunia persampahan. Pembuatan kompos dari bahan sisa makanan yang sudah tidak layak untuk digunakan. Adanya pelatihan ini merupakan upaya yang membutuhkan dorongan dan support yang luar biasa terutama dari dirinya sendiri. Ketika ada keinginan maka semuanya pasti bisa. Kemudian akan dipengaruhi oleh faktor lingkungan sekitar yang mana bisa memperkuat keyakinan atau malah melemahkan keyakinan. Kegiatan pengadaan alat kebersihan dan tong sampah dilakukan pada tahun pertama dikarenakan hal ini merupakan salah satu sarana dan prasarana untuk melakukan dan menjaga kebersihan. Dilakukan pengadaan lagi pada tahun kedua dan ketiga untuk revitalisasi alat kebersihan dan tong sampah yang dianggap sudah tidak layak untuk dipakai.

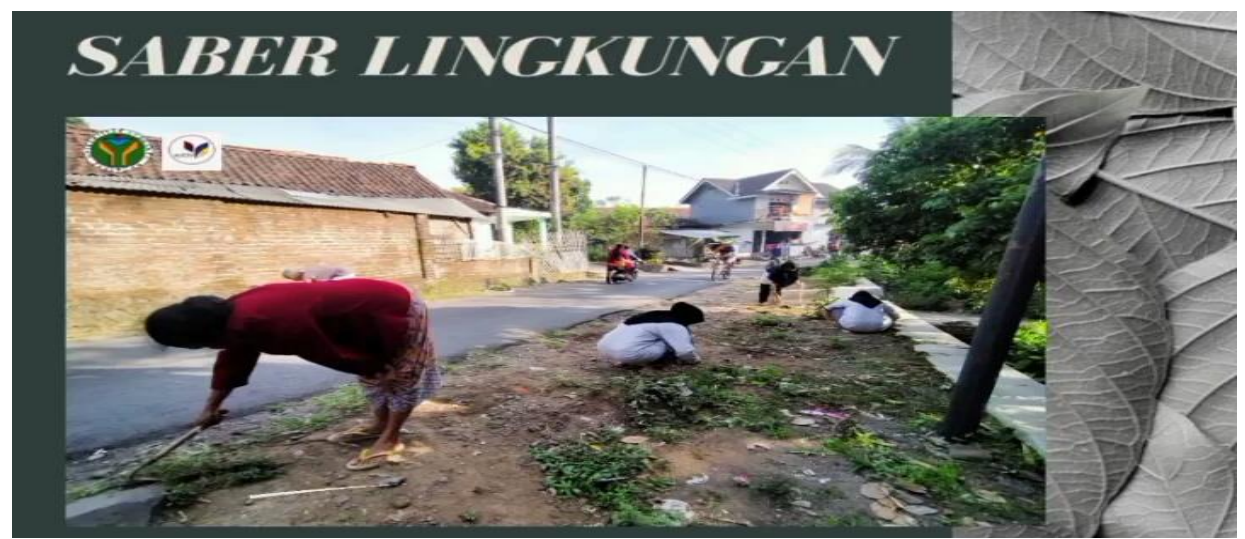

Gambar 8. Saber Lingkung Dusun Karangtengah desa Karangrejo bersama TIM Program pengabdian masyarakat Universitas Yudharta Pasuruan

Kegiatan jadwal rutin bersih desa dilakukan pada tahun pertama harapannnya bisa berlangsung selamanya. Kegiatan jadwal rutin desa ini bisa dilakukan selama satu bulan sekali. Setelah pengadaan alat kebersihan dan tong sampah maka harus dilakukan tindakan yang sebagaimana mestinya. Membangun tempat Sampah Sementara bertujuan agar masyarakat desa bisa membuang sampah di tempat itu dibandingkan sampah yang berasal dari output warga dibakar ataupun dibuang sembarangan. Mengalokasikan anggaran dana desa untuk pembangunan TPS dilakukan pada tahun kedua dan ketiga harapannya bisa terealisasi dan bisa turun pada tahun tersebut sehingga pada tahun berikutnya bisa dilakukan pembangunan Tempat Penampungan Sementara (TPS) desa Karangrejo. 


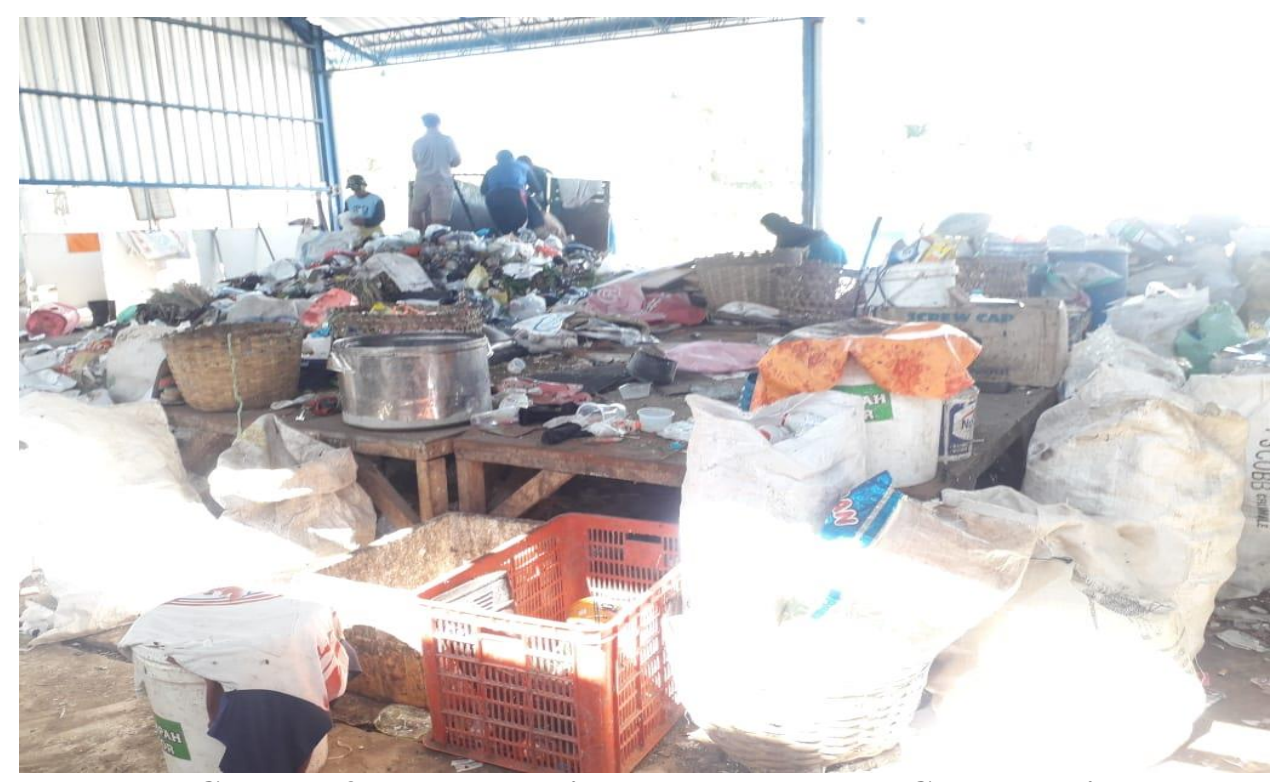

Gambar 9: Proses pemilahan sampah Desa Glagah sari

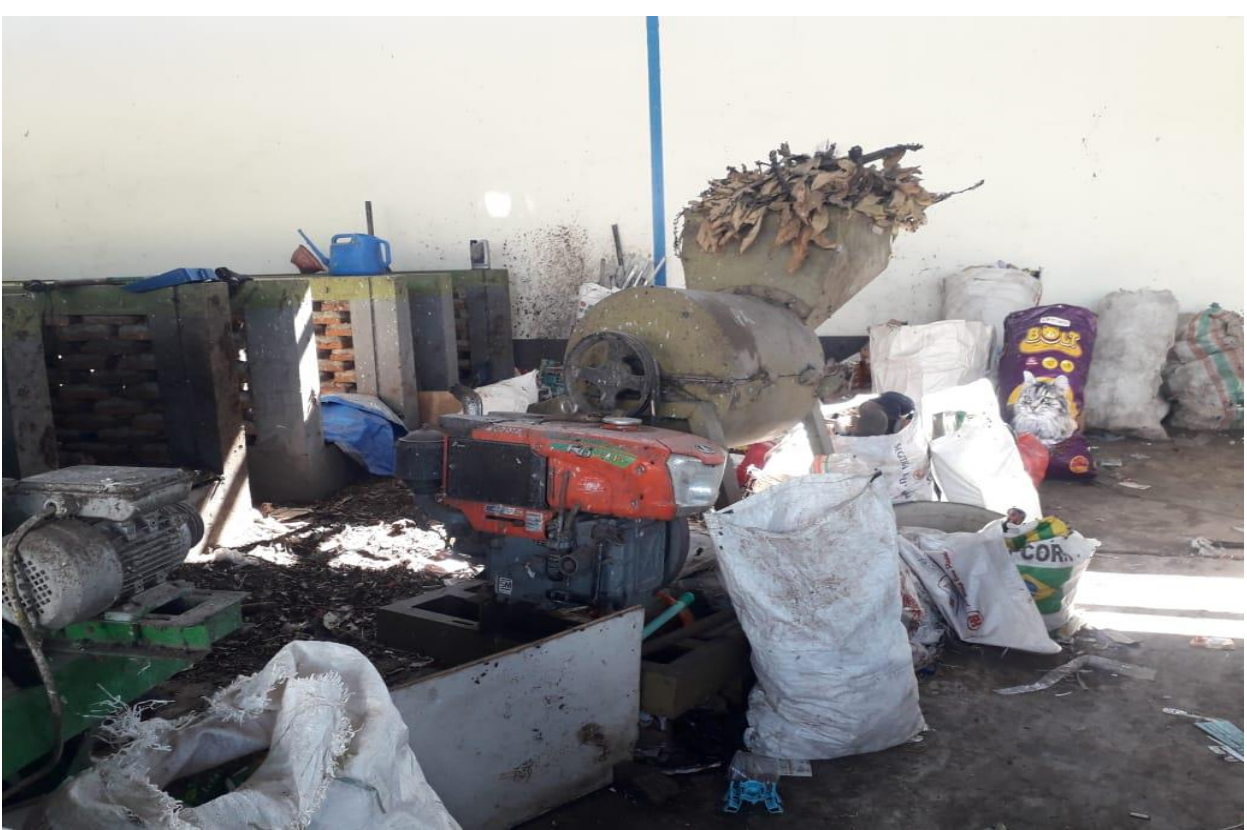

Gambar 10: tempat sampah organik Desa Glagahsari kecamatan Sukorejo.

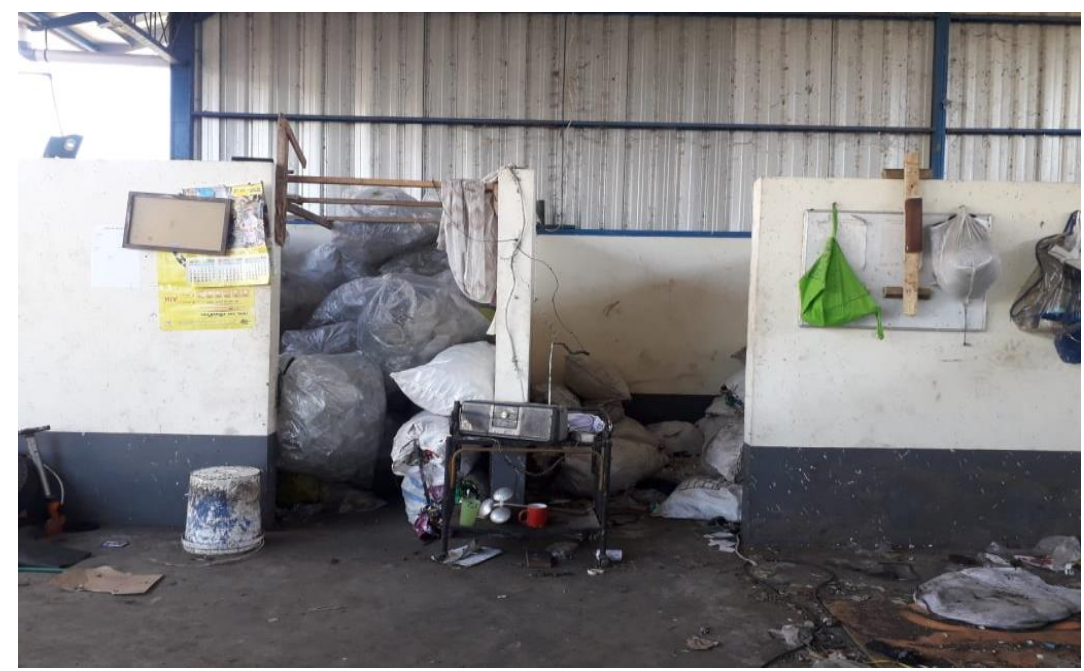

Gambar 11: Pemilahan sampah nonorganik Desa Glagahsari kecamatan Sukorejo. 


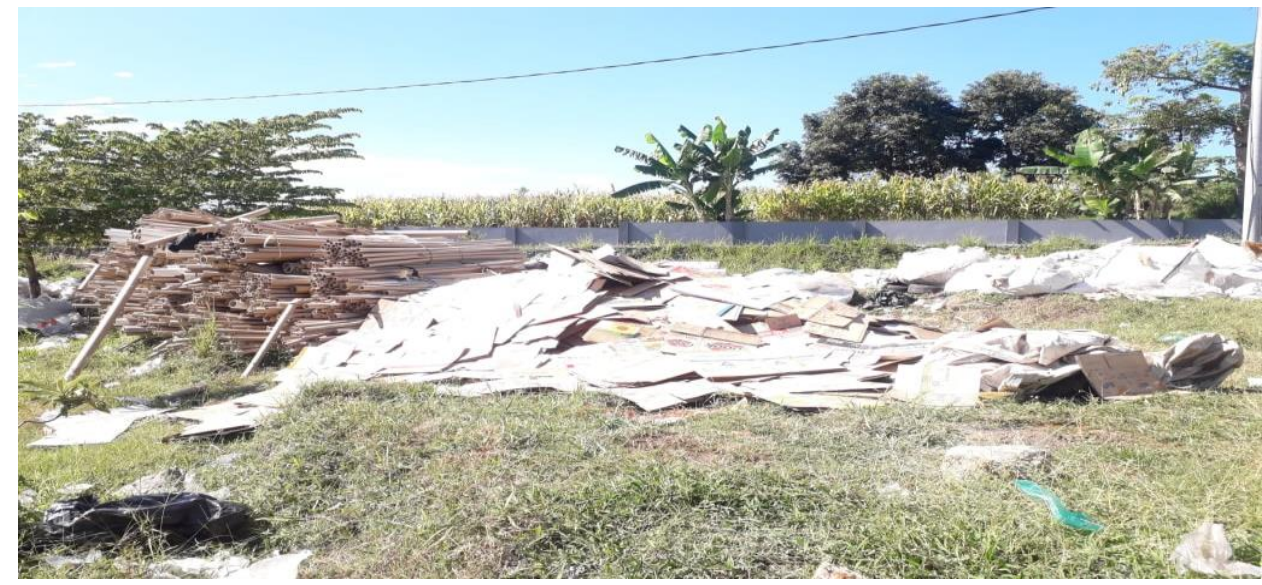

\section{Gambar 12: Pemilahan Sampah Nonorganik yang siap dijual kepada pengepul Desa} Glagahsari kecamatan Sukorejo.

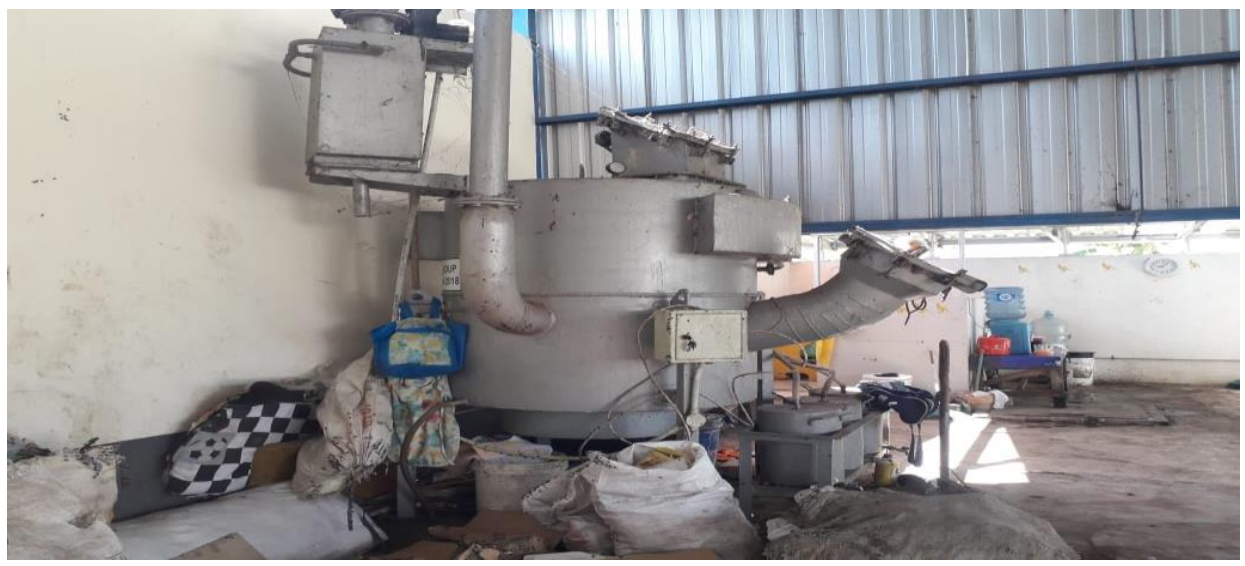

\section{Gambar 13: tempat pembakaran sampah Residu sebelum diambil oleh DLH di Desa Glagahsari kecamatan Sukorejo.}

Desa Glagahsari merupakan desa yang menjadi acuan bagi penulis dan tim untuk mendesain Tempat Pembuangan Sampah yang akan dibangun di desa Karangrejo. Pembangunan Tempat Pengolahan Sampah Terpadu (TPST) bersamaan dengan taman edukasi yang akan dilakukan pada tahun kedua dan ketiga. Setelah berdirinya TPS serta Taman Edukasi akan membuat warga sadar dengan pengelompokkan sampah dan kegunaan atau daya jualnya. Tempat edukasi pengelolaan sampah ini dibangun dikarenakan hal ini yang menunjang pengelolaan sampah menjadi barang yang berguna dan bermanfaat. Terjadi proses pemilahan ketika sampah akan dibuang ke TPS ini dengan 3 bagian (organik, nonorganik, dan residu). Pelatihan pengelolaan sampah menjadi barang yang berguna dan bermanfaat dilakukan pada tahun ketiga dan seterusnya karena sudah ada wadah yang menampung untuk mengolah sampah menjadi barang yang berguna dan bermanfaat.

Berdasarkan Sistem Informasi Pengelolaan Sampah Nasional (SIPSN) tahun 2017-2018 diketahui bahwa di kabupaten Pasuruan menghasikan 1.130 ton sampah berasal dari timbunan sampah Rumah tangga setiap harinya. Hal ini akan semakin bertambah besar karena jumlah warga atau masyarakat yang semakin lama akan semakin meningkat, serta lahan pekarangan rumah akan semakin menyempit sehingga terkadang masyarakat akan membuang sampah pada tempat dengan lahan yang masih kosong atau di sungai. Sehubungan dengan lahan desa Karangrejo Kecamatan Purwosari, Kabupaten Pasuruan- Jawa Timur yang masih cukup luas. Bapak Kepala Desa Karangrejo telah menyediakan lahan seluas $800 \mathrm{~m}^{2}$ untuk membangun Tempat Pembuangan Sampah (TPS) di Desa Karangrejo yang letaknya berada pada bagian belakang BUMDES (Badan Usaha Milik Desa) Karangrejo. 
Berdasarkan permintaan bapak Kepala Desa Karangrejo ingin mengadakan Program yang akan sehubungan dengan pengelolaaan sampah yaitu "taman edukasi sampah". Taman Edukasi sampah adalah tempat edukasi kepada masyarakat mengenai sampah, cara pengelolaan, serta manfaatnya. Sehingga menjadikan Desa Karangrejo sebagai desa percontohan dalam pengelolaan menjadi tempat rekreasi yang baik seperti kampung warna warni Jodipan, Malang- Jawa Timur yang memanfaatkan kampung yang awalnya kumuh menjadi kampung rekreasi. Hal ini memiliki tujuan untuk merubah pandangan dan pola pikir masyarakat tentang pinggiran sungai yang dianggap kumuh akan tetapi pada kenyataanya dapat dirubah menjadi kampung rekreasi yang mendapat perhatian khusus serta daya tarik warga sekitar Malang atau luarkota. Dan hal ini menjadikan beberapa kampung di sekitarnya melakukan perubahan seperti kampung TriDI (3D) yang letaknya diseberang kampung warna warni Jodipan serta kampung Biru AREMA yang berletak diseberang kampung Warna Warni Jodipan ini. Serta ada hal yang menjadi keunikan dari kampung Warna Warni Jodipan. Yaitu memberikan cinderamata kepada pengunjung sebagai ganti tiket yang biasanya berupa kertas dengan memberikan stiker di Kampung warna warni Jodipan dan memberikan gantungan kunci sederhana berbentuk buah di kampung TriDI (3D). Hal ini yang menyebabkan bapak Kepala Desa Karangrejo kecamatan Purwosari, Kabupaten Pasuruan- Jawa Timur mencetuskan ide kita dalam memanfaatkan lahan Tempat Pembuangan akhir di Desa Karangrejo menjadi tempat edukasi. Penulis mengadakan kerjasama antara ppemerintahan Desa Karangrejo bersama Universitas Yudharta Pasuruan, mewujudkan keinginan dari pihak Desa Karangrejo dan Universitas Yudharta Pasuruan sesuai dengan MOU yang sudah di sahkan oleh Rektor Universitas Yudharta Pasuruan bapak dan Kepala Desa Karangrejo Kecamatan Purwosari Kabupaten Pasuruan-Jawa Timur.

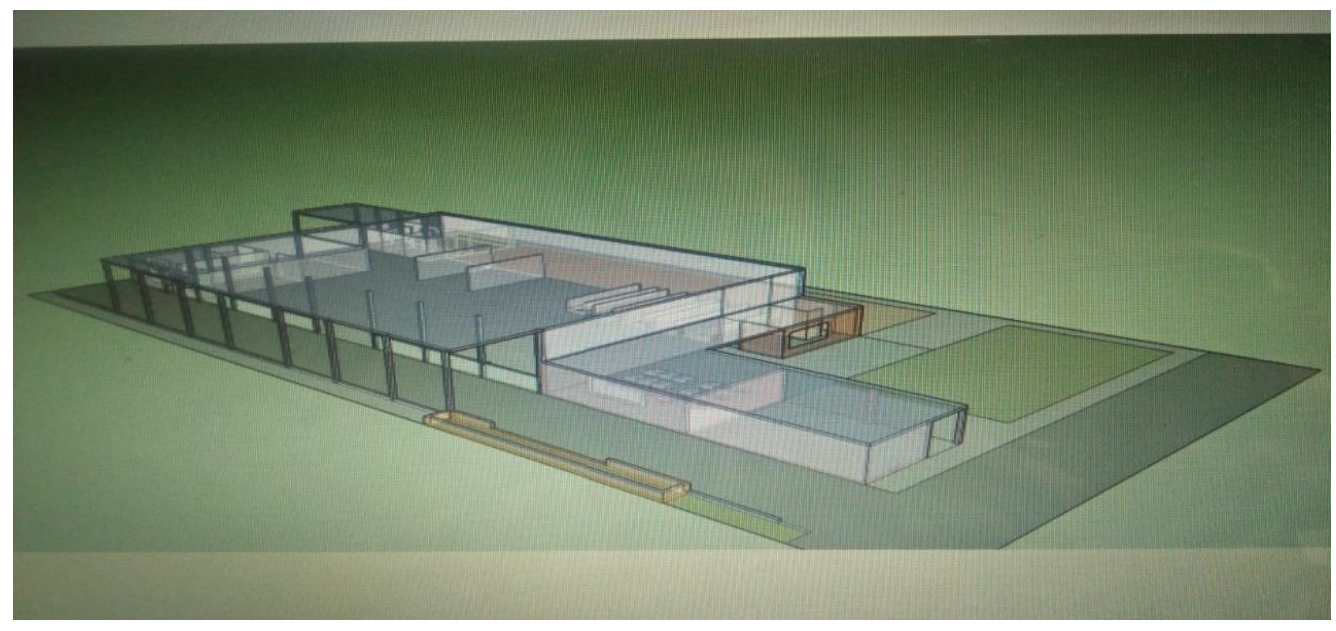

\section{Gambar 14. Design gambar rencana pembuatan "Taman Edukasi Sampah” Desa Karang Rejo}

\section{Berikut adalah denah beserta penjelasanya:}

\section{$\Rightarrow$ Bank Sampah:}

2 orang petugas melaksanakan pengepakan/packing untuk mengelompokan barang pecah belah untuk didata dan tumpukan diruangan Bank Sampah adalah sebagai berikut :

- Kertas, terutama kertas bekas di kantor, koran, majalah, kardus kecuali kertas yang berlapis (minyak atau plastik).

- Plastik bekas wadah sampo, air mineral, jerigen, ember.

- Botol bekas wadah kecap, saos, sirup, krim kopi; baik yang putih bening maupun yang berwarna terutama gelas.

- Logam bekas wadah minuman ringan, bekas kemasan kue, rangka meja, besi rangka beton.

$\Rightarrow$ Kantor:

Ruang melakukan pendataan kegiatan administrasi dan melakukan evaluasi kegiatan.

$\Rightarrow$ Rak Penyimpanan

Hasil dari pengumpulan barang pecah belah seperti kertas dan hasil kompos dapat disimpan dalam rak penyimpanan, dengan susunan dapat dilaksanakan menurut tempat.

$\Rightarrow$ Kamar mandi 


\section{$\Rightarrow$ Pintu Masuk Area Pengelolaan \\ $\Rightarrow$ Pemilahan \\ $\Rightarrow$ Tempat Pencacahan \\ $\Rightarrow$ Pencacahan Sampah Organik}

Dalam hal ini sampah yang masuk pada tempat pemilahan akan dipilah menjadi 3penumpukan yaitu sampah organik, an organik, B3. Pada proses pemilahan sampah ini dibutuhkan 3 atau 4 orang petugas untuk memilah sampah sesuai dengan jenisnya selanjutnya menempatkan wadah yang telah tersedia. Petugas menggunakan peralat alat kerja, Baju Kerja, Masker, Sarung tangan karet, Helmet, Sepatu kedap Air, Sekop, Garukan sampah, Lori dan Sapu lidi, pada waktu 1 hari itu juga harus tercapai pemilahan sampah organik dengan terseleksi.

-Tempat Pencacahan

\section{-Pencacahan Sampah Organik}

mempersiapkan mesin pencacahan sampah untuk proses penggilingan sebelum menghidupkan mesin pencacah

pengomposan ini dilakukan dengan menimbun sampah organik dengan menggunakan bak truk sampah bekas.

Pengayakan/Penyaringan

Peralatan untuk proses penyaringan adalah sebagai berikut:

-Saringan putar / Ayakan Kawat

- Sekop

Perlengkapan petugas penyaringan sampah organik adalah sebagai berikut :

-Topi/helm kerja

- Baju kerja

- Masker

-Sarung tangan

- Sepatu kedap air

- Kompos yang sudah matang dari area pengomposan dipanen dan diangkut ke tempat pengayakan kompos untuk disaring atau diayak yang dilakukan secara manual.

- Kompos yang akan disaring didiamkan terlebih dahulu, sehingga tidak terlalu lembab diayak.

- Petugas melakukan penyaringan untuk rnemperoleh ukuran partikel kompos sesuai dengan kebutuhan serta untuk memisahkan bahan-bahan yang tidak dapat dikomposkan.

- Bahan yang belum terkomposkan dikembalikan ke dalam tumpukan yang baru, sedangkan bahan yang tidak terkomposkan dibuang sebagai residu.

\section{-Proses Pengemasan dan Penyimpanan Kompos}

Peralatan dan perlengkapan pendukung untuk proses pengemasan kompos adalah sebagai berikut :

-Sealer

- Kantong plastik

-Mesin jahit karung/goni

-Timbangan

- Lori

Setelah disaring lagi dengan alat penyaring barulah kompos ini benar-benar halus, selanjutnya dipacking dan ditimbang menurut takaran lalu dijahit kemasan kantongan $1 \mathrm{~kg}, 2 \mathrm{~kg}$, atau $5 \mathrm{~kg}$ goni plastik, diberi label yang berisi informasi tentang nama kompos, jenis bahan baku, produsen kornpos, kandungan kimia, dan kegunaannya untuk tanaman atau sesuai dengan kebutuhan pemasaran. Kompos yang telah dikemas disimpan dalam gudang yang aman dan terlindung dari kemungkinan tumbuhnya jamur oleh bibit jamur dan benih gulma dan benih lain yang tidak diinginkan yang mungkin terbawa oleh angin.

\section{-Tempat Pembuangan Residu}

- Petugas pengumpul sampah B3 untuk menyiapkan tempat bebas dari genangan air, yang bersih, asri, dan luas yang secukupnya guna menampung sampah B3 yang terpilah.

-Petugas menyediakan tempat bagian dari bangunan sekunder untuk meletakan sampah residu.

-Setelah petugas mengepak Sampah B3 kemudian kemas/packing lalu ditimbang dan dapat menghubungi petugas Dinas Kebersih untuk diantar ke TPA.

-Petugas membuat jadwal kerja sama pengangkutan sampah B3 kepada supir truk sampah atau melalui instansi terkait(Dinas Kebersihan). 
Taman Edukasi sampah ini nantinya akan menjadi sebuah tempat rekreasi edukasi tentang pengelolaan sampah serta menceritakan input hingga output sampah dari masyarakat serta pengelolaan kompos secara besar-besaran yang nantinya kompos hasil poduksi itu akan dibagikan pengunjung dengan cara pemberian satu tanaman dan kompos. Sehingga diharapkan pengunjung akan datang minimal 1 bulan sekali untuk melihat tanaman yang ia tanam apakah tumbuh atau mati. Serta kompos ini akan dijual di BUMDes (Badan Usaha Milik Desa) dengan tujuan menambah dana desa dan pengurangan biaya dalam revitalisasi Tempat Pembuangan Sampah tersebut.

\section{SIMPULAN}

Desa Karangrejo ini memiliki Sumber Daya Manusia yang sangat baik dengan dibuktikan aktifnya para Kader PKK serta Karangtaruna dan pemuda yang ada. Serta lahan kosong yang terdapat di sekitar desa tersebut. Hanya saja belum terlaksananya sistem dan masih terbengkalainya programpogram yang ada karena pekerjaan dan pencapaian dari program yang telah dibuat sebelumnya.

Universitas Yudharta Pasuruan bersama dengan pemerintahan Desa Karangrejo, Dinas Lingkungan Hidup, serta Forum Kabupaten Pasuruan Sehat mengadakan MOU agar terlaksananya pengelolaan sampah yang baik dan sesuai harapan. Tentunya penulis masih memantau serta melakukan sosialisasi selama terlaksananya Pengelolaan sampah yang baik sesuai harapan semua pihak.

\section{SARAN}

Hal-hal yang harus dilakukan oleh pemerintah desa karangrejo agar tercapai program ini adalah :

1. Kegiatan Bersih Desa setiap sebulan 1x

2. Mengalokasikan Anggaran dana desa untuk pembangunan TPS.

3. Pembangunan Tempat penampungan Sampah Sementara.

4. Pengadaan alat Kebersihan dan tong sampah.

5. Pembangunan Tempat Penampungan Sampah Terpadu.

6. Pembangunan Taman Edukasi Sampah.

7. Pengelolaan sampah organik menjadi pupuk secara masal sebagai oleh-oleh pengunjung.

\section{UCAPAN TERIMA KASIH}

Penulis dan Tim mengucapkan terimakasih kepada para pihak terkait yang telah dan akan melaksanakan program tentang pengelolaan sampah ini, berikut adalah nama-nama pihak yang telah membantu kegiatan penulis dan tim:

1. Tuhan Yang Maha Esa

2. Dr. Kholid Murtadlo, S.E., M.E. selaku Kepala Rektor Universitas Yudharta Pasuruan.

3. Ahmad Fauzi selaku Kepala Desa Karangrejo.

4. Seluruh masyarakat Desa Karangrejo

\section{DAFTAR PUSTAKA}

Dalam, M., Sampah, M., Dusun, D. I., Desa, P., Kecamatan, S., Kabupaten, G., \& Yogyakarta, S. (2017). Hubungan tingkat pengetahuan dan sikap terhadap perilaku masyarakat dalam mengolah sampah di dusun padukuhan desa sidokarto kecamatan godean kabupaten sleman yogyakarta. April 2013. https://doi.org/10.12928/kesmas.v6i3.1055

Diajukan, S., Fakultas, K., Tarbiyah, I., Salah, M., Syarat, S., Gelar, M., \& Pendidikan, S. (2017). Skripsi Diajukan Kepada Fakultas Ilmu Tarbiyah dan Keguruan untuk Memenuhi Salah Satu Syarat Mencapai Gelar Sarjana Pendidikan (S.Pd)

Elamin, M. Z., Ilmi, K. N., Tahrirah, T., Zarnuzi, Y. A., Suci, Y. C., Rahmawati, D. R., Dwi P., D. M., Kusumaardhani, R., Rohmawati, R. A., Bhagaskara, P. A., \& Nafisa, I. F. (2018). Analysis of Waste Management in The Village of Disanah, District of Sreseh 
Sampang, Madura. Jurnal Kesehatan Lingkungan, 10(4), 368. https://doi.org/10.20473/jkl.v10i4.2018.368-375

Faizah. (2008). Pengelolaan Sampah Rumah Tangga Berbasis Masyarakat. Skripsi, 1-154.

Ii, B. A. B., \& Teori, A. D. (2014). No Title. 6-46.

Nugroho, M. B. (2013). 済無No Title No Title. Journal of Chemical Information and Modeling, 53(9), 1689-1699. https://doi.org/10.1017/CBO9781107415324.004

Penanggulangannya, D. A. N. K. (2016). Jurnal Kesehatan Masyarakat A SITUATION ANALYSIS OF WASTE PROBLEM IN YOGYAKARTA. 11(2).

Sipil, J. T., Sriwijaya, U., Besar, B., \& Sumatera, P. (2018). KAJIAN INFRASTRUKTUR PENGOLAHAN SAMPAH DI KAWASAN BERKEMBANG JAKABARING KELURAHAN 15 ULU KOTA PALEMBANG. 2(1), 130-138.

Subekti, S. (2008). PENGELOLAAN SAMPAH RUMAH TANGGA $3 R$ BERBASIS MASYARAKAT. 24-30.

Terranova, Pablo Lombeida, 1999. (1999). No 主観的健康感を中心とした在宅高齢者に おける 健康関連指標に関する共分散構造分析Title. ALI ASADZADEH (2017)the Role of Tourism on the Environment and Its Governing Law.Electic Journal of Biology 13., 3, 1-8. https://doi.org/10.5860/choice.41-2927.14. 